\title{
The Role of Mass Media in The New Normal Era Pandemic Time COVID-19 in Banda Aceh City
}

\author{
Almukarramah ${ }^{1}$, Ainal Fitri' ${ }^{2}$, Fitri Melia Sari $^{3}$ \\ ${ }^{1}$ Faculty of Teacher Training and Education, Serambi Mekkah University, Banda Aceh \\ ${ }^{3}$ Islamic communication and broadcasting program Universitas Serambi Mekkah Banda Aceh \\ ${ }^{3}$ Islamic communication and broadcasting program UIN ar-Raniry Banda Aceh
}

\begin{abstract}
Communication and the masses have a strategic role in responding various problems that exist. In fact, communication and mass can be a form of early education that directly targets the wider community effectively and efficiently. The main discussion in this research is related to the important role of mass communication in the midst of the COVID-19 pandemic, as a form of prevention and early education to the public. The results of this study are, first, that communication and the masses have a central role in responding to the COVID-19 pandemic. Second, that the problems caused by the COVID-19 pandemic which has become a global problem have the potential to trigger a new social order or reconstruction, thus it is necessary to have close communication between stakeholders and the community in responding to this problem.
\end{abstract}

Keywords: Communication, New Normal Era, COVID-19, Mass Media

\section{Introduction}

Communication and the masses have a crucial role in the midst of the COVID-19 pandemic, which has been declared a global pandemic by the world health organization, namely WHO (World Health Organization). Especially in Indonesia, various expert predictions say that the pandemic will not end in the near future. 1 Thus, in responding to this pandemic, an effective and efficient communication pattern is needed to provide understanding to the public regarding the handling of this pandemic(Keane et al., 2021).

Communication is a form of the word translated from English Communication, according to its history, the word began to develop in the United States which came from newspaper elements, namely journalism. 2 The definition of communication in a simple definition, explained by Harold D. explain the message, can be done or translated in order to answer the question, "Who conveyed, what was conveyed, through what channels, to whom and what effect." (Solten Rajagukguk \& Olilia, 2020)

In the midst of the COVID-19 pandemic, communication is an important step in conveying information that is needed by someone or the public. Furthermore, communication is of other importance in dealing with COVID-19. With the policy of social restrictions, communication and the masses become an option for conveying information to the public. Responding to various problems arising from the COVID-19 pandemic, public communication is the best choice in the processsocial interactions that must keep going in the midst of a pandemic. The definition of public communication is one of the main needs, as well as communication carried out in front of many people or the general public. Public communication is the process of delivering messages in the form of information(Syaipudin, 2020). In the process, public communication requires means, it can be through mass media, whether printed, electronic or online.

Public communication in the process is divided into two, namely oral and written communication. Public communication in its pronunciation is often referred to as communication and mass. However, from this understanding, public communication tends to be considered to have a broader meaning than communication and the masses. In more 
detail, communication and mass are communications which in the process use a medium in conveying a message (Gumantan, Mahfud, \& Yuliandra, 2020).

Public communication is often found in face-to-face activities, for example public lectures, sermons, mass meetings, briefings, lectures, and others, involving large masses of people. In its delivery, public communication is a one-way form of communication, namely directly to the wider community or the general public. In more detail, communication and the mass in its delivery involve an element of the existence of a media that is involved in the delivery of this information. Not infrequently, in communication and the mass it involves several mass media at the same time which are used as a forum for conveying information to the public(Hayashi, 2021).

Communication and the masses generally disseminate information that is open to the public. However, apart from this concept, public communication is often carried out in small forums such as briefing forums, sentiaji, panel discussions, seminars and member meetings. Through understanding, public communication can also be interpreted asgroup communication, if viewed from the background of the place and situation limited (Simanjuntak \& Fitriana, 2020). Before radio was used as a source of information for public communication, communication was often carried out directly in the open field to convey information. Direct public communication even though in this modern era, is still widely carried out, especially in the lead-up to the election with as many mass directors as possible(Simsek \& Simsek, 2020).

Mass Media is an institution or institution that has a series of cultural and information production activities carried out by various types of communication and mass to be distributed to audiences in accordance with prevailing habits. The concept of media according to the results of research that has been carried out by experts is a communication between humans, which begins with the use of certain tools or media, and in its implementation, communication has not used voice or gesture movements (body movements)(Jungherr, Schroeder, \& Stier, 2019). For example, looking at the model or form of communication carried out in pre-civilization, at that time communication was carried out by humans using paintings on cave walls, through writing and through maps as a form of information exchange carried out(Wright, 2020). As quoted by Nunik Solichatun, according to Gerlach and Ely said that the media when understood in broad terms is human, material or events that build conditions that enable students to acquire knowledge, skills or attitudes.

Mass media, in terms of its benefits, is a forum for channeling communication to the wider community or the masses. Any information that will be conveyed to a wide audience by using the medium in conveying it is called mass communication, meanwhilethe medium is called mass media or mass media in English(Fatema \& Lariscy, 2020). Mass media is an acronym for mass media communication. It is called mass media because there is a mass character that is attached to or owned by the media itself(Kleinnijenhuis, Van Hoof, \& Van Atteveldt, 2019).

Mass media is a form of communication aimed at a number of general audiences, in large numbers, and through print or electronic media, and with this form of communication, the information disseminated can reach various elements of society. The mass media is a source of power for tools of control, management and innovation in society that can be utilized as a substitute for other strengths or resources(Izydorczyk, Sitnik-Warchulska, Lizińczyk, \& Lipowska, 2020).

The characteristics of the mass media are as follows: a. Mass media publicity is basically intended for the general public, there are no restrictions on who can or should read, watch, or listen and who may not read, watch or listen. b. The universality of the mass media is general in conveying material to the public(Zhang, Zhang, \& Shen, 2020). 
Mass media is basically divided into two categories, first, printed mass media and second, electronic mass media. Print media that can meet the criteria as mass media are newspapers and magazines, while electronic broadcast radio, television, film and online media (internet). Various methods and media can be used in the concept of communication and mass, but in this study it is more conical and leads to the effectiveness of communication in disseminating information(Jeet et al., 2020). So, regardless of the media used by the information provider, the most important thing is that the message conveyed can be well received by the recipient of the information. Because in essence, communication and the masses are targeting many groups so that the information conveyed is quickly accepted and can be applied(Tu, Zhang, Xu, \& Lu, 2020). This is especially so in difficult situations, which require the public to accept the information quickly. In order to provide research boundaries and clearly explain the direction of the research carried out in this paper, the authors cite several previous studies that have been carried out previously with studies that are identical to this paper.

First, as the results of research conducted by Tambunan, the mass media in their journey conditions are influenced by technological developments that have an impact on the pattern of human life. Communication technology and the masses are able to have an influence on broad audiences and individuals. Mentioned in the theory discussed in his research, namely the concept of the influence of communication through one stage (one step follow) and through two stages (two step follow). Communication through one stage (one step follow), which is when the information it receives directly affects the individuals receiving the information. Meanwhile, communication goes through two stages (two-step follow), namely if an individual will be affected by this information when the leader, an exalted person, or someone who is emphasized by the information he receives, is different from the research conducted by Tambunan, in This study examines the importance of the role of simple communication that can be done with a short time but makes the communication effective for the wider community. How important is it in providing proper early education as a form of anticipation, prevention and handling of cases of the spread of COVID-19.

Second, as the results of research conducted by Mendayun and Wardiana, in their research which discusses the effects of communication and mass. Which states that, the Communication program and the mass which is directly linked to a mass media, cannot have an effect on the program participants in giving different assessments of the performance of an organization. Or in detail the results of the research show that there is no significant relationship between the quality of the Citizen Report program and the public attitude of PR FM radio in viewing the performance of the Bandung City Traffic Police.

\section{Communication Effectiveness and the masses}

In the midst of the threat of the COVID-19 pandemic, communication and the masses are needed to provide education to the wider community. With mass communication, a very broad communication target will be obtained by targeting many people at one time. The level of accuracy of the information provided is an important thing that must be considered by the information provider. In this case, the communication conveyed to the community is messages in easy language but can be understood by the community(Purohit \& Mehta, 2020).

Communication is important because it is a basic human activity. With the existence of human communication can interact both between individuals and individuals with mass groups. Communication is also an important part of human social order wherever it exists, for example at home, work place, market and other places. Humans can never avoid the communication process, because communication needs become an inherent and important 
part of a person. If a person is able to carry out the communication process well, all the activities that run will go well and vice versa.16 Communication in an organizational or group structure is carried out to provide and receive information in order to influence others, sometimes even too(Derzon \& Lipsey, 2019). to provide assistance to others. Communication plays a role in solving problems, is one of the considerations in determining decisions taken, and even evaluating someone's behavior effectively

Communication effectiveness and mass, is an important part of achieving the goals of conveying information to others. With clear information provided, the purpose of communication will be achieved by the information provider(Abroms \& Maibach, 2008). Even in difficult situations, effective communication is very important and cannot be separatedin interactions to provide mutual education. With the level of effectivenesshigh, then in a process of delivering information, it will be able to progress properly, directed and primarily, namely being able to convey information as expected. And at least able to avoid any negative potential that can be caused by communication errors or communication that is not as expected.

The COVID-19 pandemic, which has been going on since May 2020 in Indonesia, and it cannot be predicted when it will end, has also become a concern for people including the wider community, apart from the debate about the mystery of COVID-19 that is still unsolved. Starting from the mode of transmission, what is the vaccine, and how to handle it effectively. In response to this, effective communication and mass can make a form of protection in terms of prevention and early countermeasures against the increasing spread of the Corona virus. Handling COVID-19 and the role of mass communication are two things

which becomes in an important part as Muhammad's theory,that communication plays a role in all aspects of life. This includes building interactions with the wider community regarding news and information about the COVID-19 Pandemic. So, stakeholders involved in handling COVID-19 must provide information that is clear and easily understood by the wider community.

Without communication, a vision and mission of an organization or group will be difficult to achieve and run sporadically. Communication at various times occupies a central position. Because with communication, someone will get information that is useful for his survival. Without information, someone who is engaged in various organizations will lag behind other organizations or groups. If an organization has the desire to experience progress, then information is one aspect of the need that must be met

The main purpose of communication is to obtain information, convey communication and interact with each other. Furthermore, communication can be used as an effort to influence a certain person, group or group to share certain views and goals. According to the results of the statement by the Tulungagung COVID-19 Task Force Team, it was explained that the information distributed to the public must be right on target with the right channel(Basch et al., 2020). In order to avoid miscommunication which results in difficulty receiving the information provided, there is even a misperception between the informant and the recipient of the information. Such things must be avoided, especially with regard to messages that are sensitive in nature(Sampurno, Kusumandyoko, \& Islam, 2020).

Apart from communication and mass for the community, internal communication for the government is also important in terms of handling COVID-19. Internal communication within the organization cannot be underestimated in its importance. If this communication can run smoothly and well in an organization, it will facilitate the direction and purpose of delivering information to the wider masses(Rohmah, 2020). Communication can provide information to both outsiders and insiders, taking advantage of internal interactionssocial 
process framework, gain influence, as a means of solvingproblems, considerations in decision making and facilitate the objectives of the intended changes, as well as facilitate the communication of working groups.

The sensitivity of the community in responding to information obtained through communication and the masses is also an important point that remains a concern for senders of information or messages. So that a simple but straightforward language is needed, it must be taken into consideration when the message is sent to the masses. Given, each individual in the mass has their own character. With different levels of sensitivity, language or messages that are light but easy to understand are important for the sender of the message. In translating the information to be sent, the sender of the message must consider the sensitivity of the mass targeted as the recipient of the message he wants to send.

\section{The Role of Mass Media}

Mass media becomes a simple channel in relation to communication and mass, because with mass media, a forum that carries information to the wider community will be conveyed more quickly with a broad target level. Communication experts state, relating to communication and the mass is communication through the mass media, or both have an interrelated relationship. Mass media is part or scope of understanding of communication and mass, which can also be interpreted as newspapers, magazines, radio, television, or films. In fact, in modern mass media, various sophistication of access to information sharing through internet access, which is a product of modern technology, is also counted as mass media. 22

Mass media in its utilization has an important meaning for the Task Force Team for the Acceleration of Handling COVID-19 in Tulungagung Regency, according to Didik, mass media is an important forum that can be used in conveying messages or information from sources to the wider community (recipients) by utilizing communication tools such as newspapers. , film, radio and television. 23

Several mass media are divided into several types, namely by the following classification, first, namely print media including newspapers, books, magazines as well as leaflets and pamphlets. Second, electronic media includes television, radio, Digital Video Disc (DVD) and Video Compact Disc (VCD). Third, online media includes internet websites and is currently the media that is currently most in demand by various groups, including the most dominating, namely from teenagers to obtain

information.

\section{Method}

The research method used is a qualitative research method. Creswell explained that qualitative research is defined as an approach or search to explore and understand a central phenomenon (Raco, 2010). The data collection technique that we do is using google form. Researchers use the google form because the google form is faster and wider for distributing questionnaires to subjects, on the other hand, because of this social distancing policy, it is not possible if we use the direct interview method. This research will be conducted in Banda Aceh City, Prov. Aceh. As for the subjects in this study were all the people of Banda Aceh City.

\section{Data analysis method}

In data analysis techniques in this study, using qualitative analysis techniques by conducting grounded theory methods (Ayu and Budiasih, 2013). The process using grounded theory is carried out by coding and categorizing data on the influence of mass 
media in the dissemination of health protocols in the new normal era during the COVID-19 pandemic in Banda Aceh City. In data analysis using grounded theory, it begins with an open coding process in which, (1) identifies accessers or connoisseurs of mass media in Banda Aceh City, (2) categorizes and describes the symptoms contained in the results of interviews via google form and WhatsApp. .

Then after the open coding stage, it is continued with the axial coding stage, which at the axial coding stage brings together various categories of research in the form of an arrangement and this is a combination of inductive and deductive thinking to respond to the role of communication and mass media in the new normal era during the COVID-19 pandemic. in the city of Banda Aceh. And lastly, it does selective coding. Selective coding aims to select core categorizations and connect other categories to mass media accessers or connoisseurs in Banda Aceh City during the COVID-19 pandemic in Banda Aceh City.

The location of this research examines the various potentials that occur in the development of the role of mass communication in providing understanding to the public in the midst of the COVID-19 pandemic. The presence of communication and the masses is one of the quick steps that can target various levels of society in providing information, education, and appeals regarding the handling of COVID-19. Communication can be stated as a central role in providing early protection in protecting society. Thus, the existence of communication is a shortcut to overcome the spread of COVID-19.

The research method used in this research is byusing a qualitative approach. By taking primary data from observations and interviews with informants directly found at the research location, and by utilizing secondary data that can be accessed by various modes of information related to the handling of COVID-19. Meanwhile, for data analysis techniques, simple data reduction techniques are used to obtain a level of data accuracy which is stated to have a high level of confidence.

\section{Result and Discussion}

Access to News about Health Protocols during the Pandemic The work of the mass media is to tell the events, so the main activity of the mass media is constructing various realities that will be broadcast to the public. The media compile the reality of various events that occur to form a meaningful story or discourse. According to Giles and Wiemann, language or text is able to determine the context, thus, through the language of the media they use, through the choice of words and the way of presenting the media, it can influence consumer perceptions. Construction of news in the mass media on the Corona Virus case, especially in the City of Banda Aceh, follows existing national news coverage and local / regional news coverage related to the development of the spread of the virus in Banda Aceh City.

Data on Indonesian telephone, internet, social media users according to Wearesocial 2019 based on the release of Wearesocial Hootsuite which was released in January 2019, social media users in Indonesia reached 150 million or $56 \%$ of the total population. This number is up $20 \%$ from the previous survey (2018) (wearsocial.com). In another source, based on the results of a polling study in Indonesia in collaboration with the Indonesian Internet Service Providers Association (AJII), data from March-April 2019, internet users totaled 171.17 million people or around $64.8 \%$ of the total population of Indonesia's population of 264 million people (kompas.com ).

A survey using a questionnaire distributed via google form which contains a systematic distribution of respondents' self-identity questions, media access, and the influence of health protocol coverage in the mass media. The systematics of the question is made to systematize the relationship pattern of the mass media's influence on the 
perceptions that are formed. The survey was conducted for 4 days in the period 22-26 February 2021 with 522 survey visits and 177 respondents. The number of respondents who will be used as a sample is the first 100 respondents because 100 of the population can be declared valid.

In the media access diagram, look at how big and how frequent media access is for the people of Banda Aceh City. According to media access survey data, a number of 89 respondents consume mass media every day. The mass media in question is still general in nature, both print, broadcast and digital media. The public got initial information about the Corona Virus through the mass media, amounting to $93.33 \%$ or around 93 people. Meanwhile, respondents who do not consume mass media every day are $6.67 \%$ or 6 respondents. The small percentage in the diagram "does not consume mass media every day" makes the number on "information development through the media" shows a perfect number of 100 respondents. Respondents answered that they were looking for the development of information about the Corona Virus through mass media with a specific type of media, namely social media. Respondents who answered Social media were $97.4 \%$, that is, 97 respondents were different from news portals with $2.6 \%$ or around 3 respondents.

News about the Corona Virus was also able to make respondents access social media more often than before. From this diagram it can be concluded that media access, especially social media by the people of Banda Aceh City is very high and massive / daily and the news / information obtained from social media is the basis / reference for the people of Banda Aceh City to take steps to prevent the spread of the Corona Virus. . It can be seen here that mass media, especially Android-based social media, dominates as a reference for information about Corona. This condition can be affected by the difficulty of information from person to person due to limited knowledge about Corona. The official announcement from government officials who were confused about the Cororna case before entering Indonesia was also a problem in itself because it caused a lack of centralto-regional coordination to prepare things needed to prevent the spread of Corona.

It is hoped that the role of the mass media will lead to changes in people's behavior in responding to the pandemic. According to Gunawan Permadi, Chief Editor of Suara Merdeka, the current problem is not only awareness of the health context, but changing behavior. His party is more focused on building people's perceptions from a cultural or cultural and social side(Murukutla et al., 2020).

Mass media is the main tool in disseminating various kinds of information, including being able to link government policies so that it can be spread throughout society, the strong function of persuasion makes it easy for mass media to influence audiences so that they can act according to what the media wants. All media must work together to educate the community concerned With the importance of implementing 3M, with the dedication of the entire community due to the large influence of the mass media, the implementation of health protocols in daily activities will be easy to implement, so that people have an awareness of how important it is to maintain their own health and the health of others, the efforts made by the government are aimed at to cut off the spread of the corona virus so as to create a healthy Indonesia.

The mass media can have a wide impact on audiences, both positive and negative, the mass media can bridge policies and information from the government to be conveyed to the entire public, the use of mass media is considered very effective in campaigning the $3 \mathrm{M}$ movement, because the information conveyed will quickly expand to all audiences, the mass media must educate how $3 \mathrm{M}$ is applied in everyday life, because not all people know what the $3 \mathrm{M}$ movement is, the media must promote and explain why the $3 \mathrm{M}$ movement needs to be done. 
The use of masks can reduce the risk of transmission so that it is safe when carrying out activities outside the home, maintaining physical distance can also reduce the risk of transmission because it is possible not to come into direct contact with other people who cannot yet know whether the person carries the COVID-19 virus in their body or not, get used to washing hand using soap after holding anything is also important so that it can get rid of germs and bacteria that can be harmful to the body.

In addition to the efforts of the government, journalists, journalists, and various media organizations must also take part in disseminating the $3 \mathrm{M}$ movement to the entire community, one way that can be done in spreading the $3 \mathrm{M}$ movement to the public is through the mass media, one of the functions of the mass media. namely the information function, where through the mass media information that has been collected must be packaged in such a way and then it can be disseminated to a wide audience, and then there is the persuasion function, namely the ability of the mass media to influence the audience so that they can act according to what the media itself expects.

Health Protocol Behavioral ComplianceThe study explores the main behaviors that are expected to be implemented by the community in preventing the transmission of COVID-19. The main behavior is wearing a mask, the habit of washing hands with soap and running water and keeping a distance. In this study, one question item was added, namely the use of personal hand sanitizers.

The results showed that $93.3 \%$ of 2,367 respondents or 2,202 respondents stated that they always use masks. Respondents who said they rarely or never used masks only reached $0.38 \%$ or as many as 9 out of 2,367 respondents. This shows that the use of masks among the people of Banda Aceh City is very good (above 90\%). Note that in this study the use of masks in this case has not been further studied regarding the accuracy of use. The use of masks in this case is not limited to certain types of masks. Referring to WHO and Ministry of Health guidelines on the use of masks, for the public and people who do not have symptoms, the recommended mask is a cloth mask. This mask has the advantage that it is easy to obtain / made independently / cheap, can be washed again and can be modified the motive for the sake of accessories.

As many as $80.44 \%$ or 1,904 respondents from 2,367 respondents stated that they always wash their hands with soap when entering or leaving a place. The description of the results of the study in Banda Aceh regarding hand washing also looks quite encouraging. This condition is not separated from the widespread provision of means of washing hands with soap in various places, even in front of people's homes. This also provides an illustration of the high concern among the community in terms of washing hands with soap. However, there were still $19.56 \%$ of respondents who stated that sometimes / rarely have they never washed their hands with soap. Compared to the behavior of using masks, this figure seems to be left behind. Regarding the use of personal hand sanitisers as another way to be able to sterilize hands from viruses, the results showed that only $69.79 \%$ of respondents stated that they always carry them. Thus as many as $31 \%$ more respondents are not used to using hand sanitizers. This may be related to additional costs and some information that emphasizes it is more important to wash hands with soap than to use hand sanitizers. As many as $66.33 \%$ of respondents or 1,570 respondents out of 2,367 respondents stated that they always keep their distance when communicating outside the home with the other person they are talking to. As many as $7.06 \%$ stated that they rarely / never keep their distance when communicating with the other person. The protocol for maintaining distance is the protocol that seems the most difficult to fulfill by the community.

The results of the study show that the Health Protocol Behavioral Compliance, the use of masks is the one that can most be obeyed by the people of Banda Aceh City. Ease of 
handling and provision and its personal nature make this protocol the highest level of compliance. The implementation of the mass mask campaign carried out by the Banda Aceh City Government in February March may also play a role in influencing this compliance. The amount of information with an emphasis either directly or indirectly on the use of masks, provides easy access to information from the public. The protocol for maintaining distance is the most difficult protocol for the people of Banda Aceh to obey. This protocol requires a normative agreement between communication actors and this is one that may not always be possible for someone who tries to personally maintain a distance. On the other hand, the critical analysis that can be given is that a comprehensive communication strategy that is not partial or highlights one side may need to be rethought. Overall, it can be concluded that the level of community compliance in Banda Aceh City in health protocols for the prevention of COVID transmission is mostly good. However, consistency in behavior is the main key so that sustainable IEC with the support of various other instruments is needed as well as continuous monitoring to be able to put the strategy in the right position.

\section{Acknowldegent}

Thanks to friends for their help both morally and materially so that this research can be carried out and get better results and can be used by the whole community.

\section{References}

Abroms, L. C., \& Maibach, E. W. (2008). The effectiveness of mass communication to change public behavior. In Annual Review of Public Health. https://doi.org/10.1146/annurev.publhealth.29.020907.090824

Basch, C. H., Hillyer, G. C., Erwin, Z. M., Mohlman, J., Cosgrove, A., \& Quinones, N. (2020). News coverage of the COVID-19 pandemic: Missed opportunities to promote health sustaining behaviors. Infection, Disease and Health. https://doi.org/10.1016/j.idh.2020.05.001

Derzon, J. H., \& Lipsey, M. W. (2019). A Meta-analysis of the Effectiveness of MassCommunication for Changing Substance-use Knowledge, Attitudes, and Behavior. In Mass Media and Drug Prevention. https://doi.org/10.4324/9781410603845-11

Fatema, K., \& Lariscy, J. T. (2020). Mass media exposure and maternal healthcare utilization in South Asia. SSM - Population Health. https://doi.org/10.1016/j.ssmph.2020.100614

Gumantan, A., Mahfud, I., \& Yuliandra, R. (2020). Pemberlakuan New Normal Dan Pengetahuan. Sport Scienc and Education Journal.

Hayashi, K. (2021). How Could COVID-19 Change Scholarly Communication to a New Normal in the Open Science Paradigm? Patterns. https://doi.org/10.1016/j.patter.2020.100191

Izydorczyk, B., Sitnik-Warchulska, K., Lizińczyk, S., \& Lipowska, M. (2020). Socio-cultural standards promoted by the mass media as predictors of restrictive and bulimic behavior. Frontiers in Psychiatry. https://doi.org/10.3389/fpsyt.2020.00506

Jeet, G., Thakur, J. S., Prinja, S., Singh, M., Nangia, R., Sharma, D., \& Dhadwal, P. (2020). Protocol for a systematic review of reviews evaluating effectiveness of mass media interventions for prevention and control of non-communicable diseases. BMJ Open. https://doi.org/10.1136/bmjopen-2019-032611

Jungherr, A., Schroeder, R., \& Stier, S. (2019). Digital Media and the Surge of Political Outsiders: Explaining the Success of Political Challengers in the United States, Germany, and China. Social Media and Society. https://doi.org/10.1177/2056305119875439 
Keane, L., Kite, J., Grunseit, A., Vineburg, J., Tawil, V., \& Thomas, M. (2021). "Perceived fit," "understanding," and "communication": Key factors underpinning stakeholder and partnership engagement with the Make Healthy Normal campaign. Health Promotion Journal of Australia. https://doi.org/10.1002/hpja.302

Kleinnijenhuis, J., Van Hoof, A. M. J., \& Van Atteveldt, W. (2019). The combined effects of mass media and social media on political perceptions and preferences. Journal of Communication. https://doi.org/10.1093/joc/jqz038

Murukutla, N., Cotter, T., Wang, S., Cullinan, K., Gaston, F., Kotov, A., ... Mullin, S. (2020). Results of a mass media campaign in south africa to promote a sugary drinks tax. Nutrients. https://doi.org/10.3390/nu12061878

Purohit, N., \& Mehta, S. (2020). Risk Communication Initiatives amid COVID-19 in India: Analyzing Message Effectiveness of Videos on National Television. Journal of Health Management. https://doi.org/10.1177/0972063420935659

Rohmah, N. N. (2020). Media Sosial Sebagai Media Alternatif Manfaat dan Pemuas Kebutuhan Informasi Masa Pandemik Global Covid 19 (Kajian Analisis Teori Uses And Gratification). Al-I'lam: Jurnal Komunikasi Dan Penyiaran Islam.

Sampurno, M. B. T., Kusumandyoko, T. C., \& Islam, M. A. (2020). Budaya Media Sosial, Edukasi Masyarakat, dan Pandemi COVID-19. SALAM: Jurnal Sosial Dan Budaya Syar-I. https://doi.org/10.15408/sjsbs.v7i5.15210

Simanjuntak, D., \& Fitriana, R. (2020). Culture Shock, Adaptation, and Self-Concept of Tourism Human Resources in Welcoming the New Normal Era. Society. https://doi.org/10.33019/society.v8i2.200

Simsek, E., \& Simsek, A. (2020). New Literacies for Digital Citizenship. Contemporary Educational Technology. https://doi.org/10.30935/cedtech/6097

Solten Rajagukguk, S., \& Olilia, S. (2020). Peran Media Massa Terhadap Masyarakat Di Saat Pandemi COVID 19 Solten Rajagukguk 1 Sandra Olifia 2. Peran Media Massa Terhadap Masyarakat Di Saat Pandemi Covid-19.

Syaipudin, L. (2020). Efektifitas Media Komunikasi di Tengah Pandemi: Respon Gugus Tugas Percepatan Penanganan Covid-19 Kabupaten Tulungagung. Kalijaga Journal of Communication. https://doi.org/10.14421/kjc.12.06.2019

Tu, M., Zhang, B., Xu, J., \& Lu, F. (2020). Mass media, information and demand for environmental quality: Evidence from the "Under the Dome." Journal of Development Economics. https://doi.org/10.1016/j.jdeveco.2019.102402

Wright, V. (2020). Étude de la polychromie des reliefs sur terre crue de la Huaca de la Luna Trujillo, Pérou. Étude de la polychromie des reliefs sur terre crue de la Huaca de la Luna Trujillo, Pérou. https://doi.org/10.30861/9781407302959

Zhang, Z., Zhang, Y., \& Shen, D. (2020). The Dynamic Correlations Between Mass Media News and New Media News in Stock Market. Frontiers in Physics. https://doi.org/10.3389/fphy.2020.00179 